\title{
PLIGHT OF THE PARENTS OF THE FILIPINO LEARNERS IN THE IMPLEMENTATION OF THE MODULAR DISTANCE LEARNING
}

\section{FITZGERALD C. KINTANAR, SUZETTE T. ELLADORA \& FRENAH R. CUIZON}

Cebu Technological University-Argao, Cebu Philippines

\begin{abstract}
Both academics and parents have been affected by the COVID-19 pandemic's widespread incidence. Modular Distance Learning was established as an early response to the global health crisis to assure educational continuity. The primary goal of this study is to learn about the challenges parents face when implementing Modular Distance Learning at Sibonga Central Elementary School (SCES), Sibonga, Cebu, Philippines during the School Year 2020-2021.

These issues were discovered using a quantitative technique, which included conducting surveys with the 70 participants who were selected through grab or opportunity sampling. The descriptive survey method was utilized in gathering and interpreting the data findings. Research findings revealed that parents are having a very serious problem in terms of communication, wherein the indicator that has the highest weighted mean states that "I am not knowledgeable enough when it comes to having a system in facilitating instructions to my child/children" and in terms of learning at home, wherein the indicator that has the highest weighted mean states that "My child/children cannot focus entirely on academic work when they are doing it at home". On the other hand, the totality of the problems encountered by parents is under the categorical response Strongly Agree and interpreted as Very Serious Problem. Moreover, the overall standard deviation entails that the responses are not widely spread, or it is homogenous which means that the results are highly reliable.

According to the findings of this study, educators and policymakers may consider establishing a Home-School Link program for parents to learn about effective modular distance learning at home. This could serve as a springboard for further development and support of Modular Distance Learning as one of the Department of Education's suggested and executed options based on the existing Learning Continuity Plan(LCP) during the CoViD-19 pandemic.

KEYWORDS: Covid-19 pandemic, modular distance learning, parents, challenges \& Learning Continuity Plan
\end{abstract}

Received: Jul 03, 2021; Accepted: Jul 23, 2021; Published: Aug 27, 2021; Paper Id: IJESRDEC20216

\section{INTRODUCTION}

The COVID news broke on March 6, 2020, like an explosion, affecting academic institutions all around the world (Sankar, 2020). To avoid the spread of the coronavirus disease, schools at all levels around the world must cease face-to-face sessions. To solve student learning continuity, schools must adopt a new learning model. Educators, administrators, and other interested parties will meet to discuss this issue.

The Philippines is one of the countries hardest hit by the pandemic around the world. Despite the fact that face-to-face classes have been discontinued, the Philippine educational system has been attempting to find ways to continue educating students. The Philippines is currently undergoing a transformation to a new normal of education, with educators' constant innovations and active participation from other stakeholders serving as the driving factors behind its success (OECD, 24 September 2020). 
Parents and guardians play various roles in Modular Distance Learning, such as Module-ator, Bundy-clock, and Home Innovator, according to Department of Education (DepEd) Order No. 018, Series of 2020 on Policy Guidelines for the Provision of Learning Resources in the Implementation of the Basic Education Learning Continuity Plan (CLP). As a Module-ator, they are responsible for collecting and submitting printed Self-Learning Modules (SLMs) from and to schools or barangay halls at the start and conclusion of each week, as agreed by the parents and the school. They can check their child's timetable or weekly plan as a Bundy clock. They can see that it is being followed to avoid cramming or delays in submission, which may influence the child's performance, due to the large number of subjects or tasks to be completed. Finally, as a Home Innovator, they may be able to establish a productive learning environment for their child, allowing them to focus more on learning. It can be a well-lit, well-ventilated room with few to no distractions.

Even before the pandemic started, parents find it difficult to teach their children, given that some are not able to go to school and cannot even comprehend simple instructions. Hence, institutions were there to educate them and give them better learning, and their parents cannot give them at home. For some, education has been a great tool to raise someone's life out of poverty. Truly, the best way to become successful is through education. Yet, the world has been paralyzed for a year because of the pandemic. As a result, there are more abrupt shifts, particularly in the style of learning, making it more difficult for parents and guardians to help children understand the lessons supplied through modules, whether hardbound or electronic (Journal of Education and Educational Development 7(1), 09-26, 2020).

As necessary as these programs are for fulfilling current demands, they have created a challenging pattern for parents who work from home while simultaneously ensuring that their children's learning process remains uninterrupted during COVID-19. As a result, the study would like to find out what issues parents had with the implementation of Modular Distance Learning at Sibonga Central Elementary School (SCES) in the School Year 2020-2021. The researchers are motivated to perform a study on the plight of Filipino learners' parents in the application of the modular learning modality in this setting.

\section{METHODS}

This study utilized the descriptive survey method as means of gathering and interpreting the data findings. This method described the plight of the parents of elementary learners in the implementation of the modular learning modality in the selected parents of Sibonga Central School for S.Y 2020-2021. The researchers utilized an adapted questionnaire as a medium in collecting data and gathering information as a basis in formulating some further recommendations.

The study was conducted at the selected elementary parents of Sibonga Central Elementary School in the first district of Sibonga Municipality, Cebu Philippines. The school is also known as SCES, which 55 kilometers are away from the city. It is located on a plateau 250 meters from the National Highway near the public market of Sibonga, Cebu Philippines.

The respondents of the study were chosen using an accidental sampling technique in which ten respondents in each grade level of elementary parents in Sibonga Central Elementary School are involved.The researchers utilized an adapted questionnaire from Noemi Dado (2020), which served as the main tool for gathering data to answer the research questions. The questionnaire consisted of 15 statements that anchor on the problems encountered by parents in the implementation of modular distance learning. The respondent rated herself/himself on each of the items by checking the column which best indicates the degree of manifestation of the problems he/she encountered.2:54 PM 23/07/2021 
The frequency counts and percentage distribution of the respondents' profile in terms of combined monthly family income and highest educational attainment were determined using Frequency Count and Simple Percentage.

The challenges experienced by the parents in the implementation of modular distance learning were summarized, analyzed, and interpreted using the Weighted Mean and Standard Deviation (SD).Five levels were used in categorizing parents' challenges or problems wherein the range of the weighted mean would be the following:1.00 -1.75 (Agree), 1.76 2.50 (Strongly Agree), 2.51 - 3.25 (Disagree), 3.26 - 4.00 (Strongly Agree). The relationship between the performance of the faculty were analyzed using T-test.

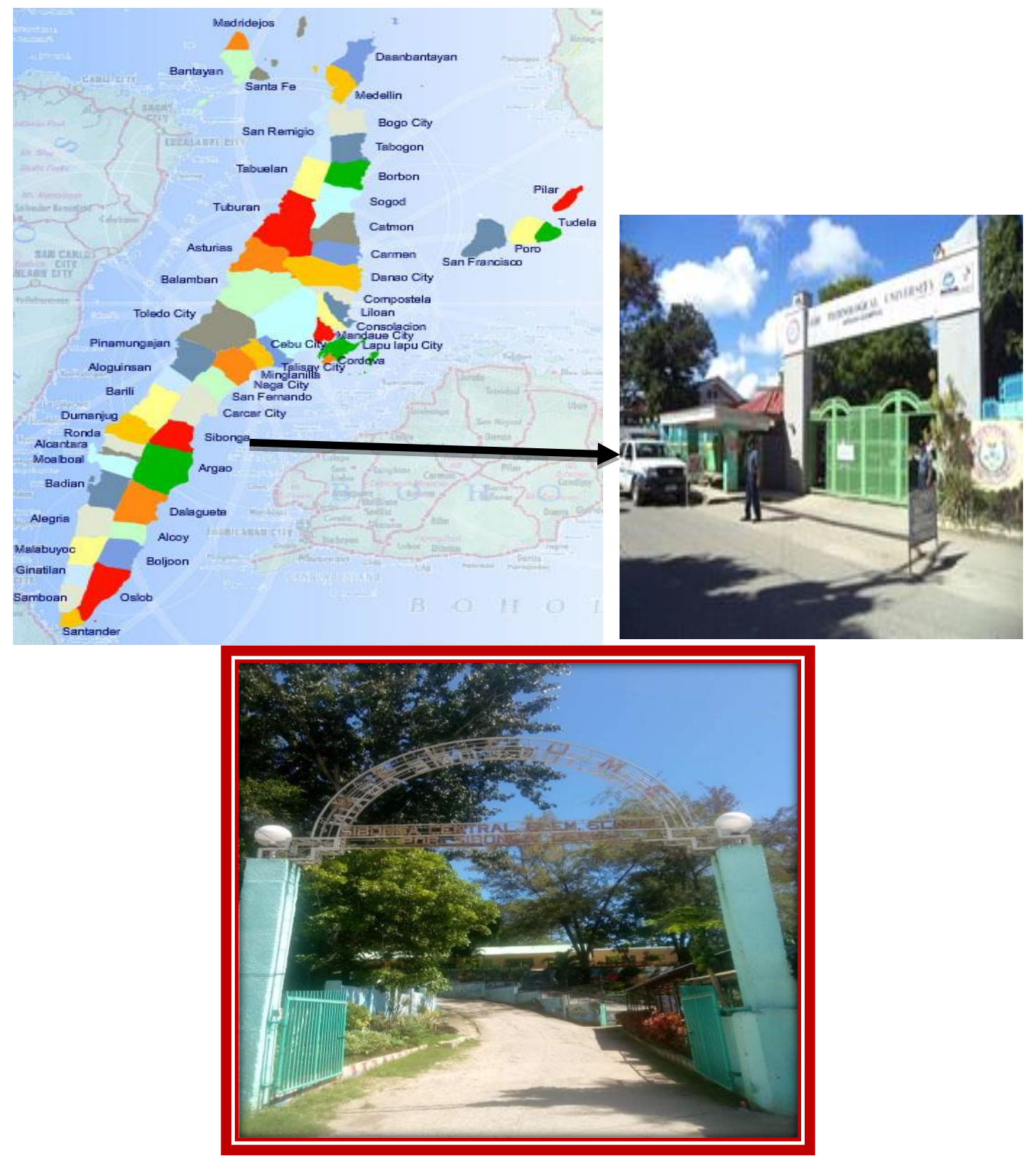

Figure 1: Map showing the Sibonga Central Elementary School - Sibonga, Cebu Philippines(https://www.google.com/search?q=map+of+cebu\&sxsrf). 


\section{RESULTS AND DISCUSSIONS}

\subsection{Highest Educational Attainment}

As shown in table 1, most of the parents, or 28 of them, are high school graduates, which has a percentage of $40 \%$. This means that majority of the parents are high school graduates. In addition, the table presents that one or $1.43 \%$ of respondents indicated that he/she was not able to attend school at all. This implies that most of the parents of the elementary students have attended school.

Parents are the most powerful influence on their children's lives, but parents have a much greater impact on their children than children have on their parents. According to studies, parents' educational levels have a significant impact on their children's accomplishments. According to the NCCP survey, 86 percent of children living in low-income families have parents with less than a high school diploma, compared to 67 percent of children with a high school diploma (but no college education) and 31 percent of children with at least one parent with some college education. As a result, students with higher-education parents may have a greater appreciation for learning, more positive ability perspectives, a stronger work orientation, and use more effective learning techniques than students with lower-education parents. Approximately 4 million babies are born each year in the United States now. One child in every eight will be born to a young woman, one child in every four will be born to a mother with a high school diploma, and nearly one child in every three will be born to poor parents. Furthermore, one out of every four children will be born to a single mother. These characteristics are associated in some manner with children who have issues in school, such as having to repeat a grade, requiring special education services, being suspended, or quitting out.

According to recent studies, children with well-educated parents do better on academic assessment tests on average than children with high school educations. According to Young and Smith, the average educational level of parents has been improving since the 1970s (1997). This implies a change in the family's ability to support and promote their children's education. According to Dornbusch, Ritter, Leiderman, Roberts, and Fraleigh, parental education level affects parenting style, which influences children's academic success (1987). According to Dombrusch et al., families with higher educational levels are more likely to be lenient and less rigid in their parenting. According to Mullis and Jenkins (1990) and White (1982), parental education has a significant impact on students' academic attainment.

Table 1: Highest Educational Attainment of Parents

\begin{tabular}{|c|c|c|}
\hline Highest Educational Attainment & $\mathbf{f}$ & $\%$ \\
\hline College Graduate & 4 & 5.71 \\
\hline College Level & 14 & 20 \\
\hline High School Graduate & 28 & 40 \\
\hline High School Level & 12 & 17.14 \\
\hline ElementaryGraduate & 6 & 8.57 \\
\hline ElementaryLevel & 5 & 7.14 \\
\hline Not AttendedSchool & 1 & 1.43 \\
\hline TOTAL & 70 & 100 \\
\hline
\end{tabular}

\subsection{Combined Monthly Family Income}

As shown in table 2, among the 70 respondents, fifty-eight (58) of them or a percentage of 82.86 had a monthly family income of below 10 957. This means that these families share the same difficulties of coping with the minimal income they are usually gaining monthly and belongs to extremely poor or low earner families. 
According to a 2018 research provided by the Philippine Statistics Authority (PSA), a family of five need at least $\mathrm{PhP} 10,481$ in monthly income to cover food and non-food necessities. With such a measure, around 89 percent of the households in the research would be considered poor. The Philippine government has been implementing ECQ and/or GCQ measures to combat the spread of COVID-19 since March 17, 2020, resulting in a significant slowdown in economic activity. As a result, this finding shows that the majority of schoolchildren come from low-income homes.

In addition, eleven (11) additional respondents had a monthly family income of 10, 957 to 10,914, or a percentage of 15.17 , and only one (1) respondent had a monthly family income of 30, 000 or more, or a percentage of 1.43 . This data suggests that the majority of the study's participants are from low-income families.

Table 2: Combined Monthly Family Income

\begin{tabular}{|c|c|c|}
\hline Combined Monthly Family Income & $\mathbf{f}$ & $\mathbf{\%}$ \\
\hline 219,140 and above & 0 & 0 \\
\hline $131,483-29,140$ & 1 & 1.43 \\
\hline $76,669-131,483$ & 0 & 0 \\
\hline $43,828-76,669$ & 0 & 0 \\
\hline $21,914-43,828$ & 0 & 0 \\
\hline $10,957-21,914$ & 11 & 15.17 \\
\hline Below10,957 & 58 & 82.86 \\
\hline Total & $\mathbf{7 0}$ & $\mathbf{1 0 0}$ \\
\hline
\end{tabular}

\subsection{Problems Encountered by Parents as to Communication}

As shown in table 3, the indicator that has the highest weighted mean of 2.26 is indicator number 1 , "I am not knowledgeable enough when it comes to having a system in facilitating instructions to my child/children," which has a categorical response of Strongly Agree and interpreted as Very Serious Problem. As a result, some parents nowadays are unable or unwilling to regularly participate in their children's education (Ho, 2009). Many parents, according to Davis (1996), have low self-esteem, while others have struggled in school and hence lack the knowledge and confidence to help their children. Parents who did not succeed in school may have a negative opinion of it (Greenwood \& Hickman,1991). Parents may be intimidated by the language, curriculum, and staff, forcing them to avoid contact with the school (Flynn, 2007). In addition, Ascher (1988) shown that restricted leave regulations and child-care requirements frequently obstruct parent engagement. Many school districts decide in advance that single and low-income working parents should not be addressed or trusted. They are not required to participate in their children's classes, assist with home learning activities, or attend meetings (Ascher, 1988).

On the other hand, the indicator with the lowest mean of 1.67 is indicator number 3, "I am experiencing hardships on how to make my child understand the content of the module," which has a categorical response of Agree and is interpreted as Serious Problem. This means that not only the children but also the parents, who were confronted with unforeseen changes and had a difficult time adjusting and helping their child/children in answering their modules, found this new manner of learning odd. Parents have become educators' collaborators because education is no longer confined to the classroom. Parents have an important role as home facilitators. Their primary role in modular learning is to form a bond with the child and guide them (Flip Science, 2020).

Cunningham \& Davis (1985) supports this assumption, claiming that while it is the parents' job to aid their children, it is the instructors' responsibility to provide parents with required information and options. Now that they have 
influence over their children's education, parents are more likely to be satisfied with the services they receive, to feel more competent in their parenting, and to be less dependant on specialists. Furthermore, the total standard deviation and its totality are both 1.05 , which is greater than 1 , indicating that the respondents' responses are dispersed and the results are less dependable. In sum, parents' communication problems received a grand mean of 1.95, with the categorical response of Strongly Agree and interpreted as Very Serious Problem, indicating that the majority of respondents agree with the claims. This means that many parents are finding it difficult to balance their work and the additional responsibility of overseeing their children's education at home.

According to a recent study by Matt Krent, etal, 60 percent of parents have been unable to find alternate schooling options. This fast transition has caught many parents off guard, bringing up some of the difficulties and obstacles that come with increased parental involvement when engaging and assisting their children in various degrees and types of remote learning.

Parents' attitudes regarding distant learning, according to (Selwyn et al.), are divided. Some parents find it rewarding to become more involved with their children's academics, while others see it as a chore. The sudden and unexpected nature of the outbreak caught parents off guard. That's why they'd have a hard time balancing their work, family, and teaching responsibilities. Their workplaces lacked the same level of sophistication. With no indication of how long the closure would last, parents attempted to work remotely or were unable to work while caring for their children and assisting them with their schooling. This tough and ambiguous situation may heighten anxiety and panic, as well as hamper time management and planning skills. Most families do not have someone to take on the full-time burden of financing distance education in a culture where 64 percent of homes have two individuals working outside the home (US Bureau of Labor Statistics, 2020). It's unsurprising that when people take on additional obligations, they suffer.

Table 3.Problems Encountered by Parents As To Communication

\begin{tabular}{|c|c|c|c|c|}
\hline Indicator & $\begin{array}{c}\text { Weighted } \\
\text { Mean }\end{array}$ & $\begin{array}{l}\text { Standard } \\
\text { Deviation }\end{array}$ & $\begin{array}{c}\text { Categorical } \\
\text { Response }\end{array}$ & Interpretation \\
\hline \multicolumn{5}{|c|}{ A. Communication } \\
\hline $\begin{array}{l}\text { 1.I am not knowledgeable enough when } \\
\text { it comes to having a system in } \\
\text { facilitating instructions to my } \\
\text { child/children. }\end{array}$ & 2.26 & 1.26 & Strongly Agree & $\begin{array}{l}\text { Very Serious } \\
\text { Problem }\end{array}$ \\
\hline $\begin{array}{l}\text { 2.I am struggling in understanding the } \\
\text { lesson/questions/assignments in the } \\
\text { module. }\end{array}$ & 1.89 & 1.11 & Strongly Agree & $\begin{array}{l}\text { Very Serious } \\
\text { Problem }\end{array}$ \\
\hline $\begin{array}{l}\text { 3.I am experiencing hard ships on how } \\
\text { to make my child understand the } \\
\text { content of the module. }\end{array}$ & 1.67 & 0.85 & Agree & Serious Problem \\
\hline $\begin{array}{l}\text { 4.Icannot accommodate all the } \\
\text { questions asked by my children } \\
\text { regarding their module. }\end{array}$ & 2.04 & 1.10 & Strongly Agree & $\begin{array}{l}\text { Very Serious } \\
\text { Problem }\end{array}$ \\
\hline $\begin{array}{l}\text { 5.I am having a hard time in knowing } \\
\text { the instructions of modules because } \\
\text { they lack further details. }\end{array}$ & 1.87 & 0.92 & Strongly Agree & $\begin{array}{l}\text { Very Serious } \\
\text { Problem }\end{array}$ \\
\hline Totality & 1.95 & 1.05 & Strongly Agree & $\begin{array}{l}\text { Very Serious } \\
\text { Problem }\end{array}$ \\
\hline
\end{tabular}




\section{Weighted Mean Interval Categorical Response Interpretation}

$\begin{array}{lll}3.26-4.00 & \text { Strongly Disagree } & \text { Least Serious Problem } \\ 2.51-3.25 & \text { Disagree Slightly } & \text { Serious Problem } \\ 1.76-2.50 & \text { Agree } & \text { Serious Problem } \\ 1.00-1.75 & \text { Strongly Agree } & \text { Very Serious Problem }\end{array}$

\subsection{Problems Encountered by Parents as to Learning at Home}

As shown in Table 4, the indicator that has the highest weighted mean of 2.16 is indicator number 7, "My Child/children cannot focus entirely on academic work when they are doing it at home," which has a categorical response of Strongly Agree and interpreted as Very Serious Problem. This implies that parents are very certain that their child/children cannot cope up with their modules as they lack focus.

This conclusion is supported by Bhamani (2020), who discovered in his research that parents found sudden school closures distressing and worried about their children's routine. Parents reported that most days of the week, schools maintain a regularly scheduled pattern, which helps students understand the value of time, scheduling, and finishing work on time. Even if parents do everything they can to keep their children engaged in meaningful activities, they are aware that they will face challenges. This time is seen by many children as a break from school.

As a result, they are averse to following a typical school regimen. Instead, they prefer to sleep and wake up whenever they want, and spend the remainder of their day playing computer games or watching cartoons or movies. This poses a danger to their social, educational, and physical development. On the other hand, the indicator with the lowest mean of 1.91 is indicator number 9, "I am worried that my child easily gets bored and unmotivated to complete all of the modules due to many distractions in the environment," which has a categorical response Strongly Agree and interpreted as Very Serious Problem. This implies that the completion of modules has brought so much worry to the parents due to a lot of distractions.

The majority of learners are experiencing problems with this new learning modality, according to Ysthr Rave P.D \& Johnine D.S (2020) research findings. Ninety percent of the participants struggled to complete their programs. Half of them don't have enough time in a week to complete all of their modules. Furthermore, most students are unable to complete all of their modules on their own, necessitating the support of others.

In addition, the totality in terms of learning at home has a grand mean of 2.01 with the categorical response, Strongly Agree, and interpreted as Very Serious Problem. To add, the overall standard deviation is 0.86, which entails that the responses of the respondents are homogeneous; therefore, their responses are highly reliable.

In relation to the results, it may be constructed that learning at home offers a very serious problem to the children and as well as the parents. It is very clear that parents are highly unfavorable in the new mode of learning as they have seen that their children lack focus and motivation in answering and completing their modules. Parents stated that their children's learning motives had diminished, according to Sonny Zaluchu's research findings (2020). Due to the enormous number of activities that must be completed in a short amount of time, less enjoyable learning techniques, and restricted social connection. For parents, the most difficult and rewarding component of modular learning is keeping their children on track while they complete their modules. 
Taking everything into consideration, parental involvement is a critical component of student success in modular settings. Parental support has been shown to have a substantial impact on students' achievement in a distance learning environment.

However, when their children participate in distant education, parents must assume new and unexpected roles and obligations, as well as increased instructional responsibility for their child's learning (Liu et al., 2010). In these trying circumstances, parents have adapted fast to meet the learning gap that has formed in their children's academic lives.

Table 4: Problems Encountered by Parents as to Learning at Home

\begin{tabular}{|c|c|c|c|c|}
\hline Indicator & $\begin{array}{l}\text { Weighted } \\
\text { Mean }\end{array}$ & $\begin{array}{l}\text { Standard } \\
\text { Deviation }\end{array}$ & $\begin{array}{l}\text { Categorical } \\
\text { Response }\end{array}$ & Interpretation \\
\hline \multicolumn{5}{|c|}{ B. Learningat Home } \\
\hline $\begin{array}{l}\text { 6. Modular Learning is time- } \\
\text { consuming. }\end{array}$ & 1.96 & 0.81 & Strongly Agree & $\begin{array}{l}\text { Very Serious } \\
\text { Problem }\end{array}$ \\
\hline $\begin{array}{l}\text { 7. My child/children cannot focus } \\
\text { entirely on academic work when they } \\
\text { are doing it at home. }\end{array}$ & 2.16 & 0.93 & Strongly Agree & $\begin{array}{l}\text { Very Serious } \\
\text { Problem }\end{array}$ \\
\hline $\begin{array}{l}\text { 8. I am sad that my child is only } \\
\text { interested in completing the modules } \\
\text { for the sake of submissions and not for } \\
\text { the sake of learning. }\end{array}$ & 2.01 & 0.79 & Strongly Agree & $\begin{array}{l}\text { Very Serious } \\
\text { Problem }\end{array}$ \\
\hline $\begin{array}{l}\text { 9. I am worried that my child easily } \\
\text { gets bored and unmotivated to complete } \\
\text { all of the modules due to many } \\
\text { distractions in the environment. }\end{array}$ & 1.91 & 0.88 & Strongly Agree & $\begin{array}{l}\text { Very Serious } \\
\text { Problem }\end{array}$ \\
\hline $\begin{array}{l}\text { 10. I am confused about some of the } \\
\text { given activities of my child's module } \\
\text { because they are not suitable for their } \\
\text { learning capacity. }\end{array}$ & 2.03 & 0.88 & Strongly Agree & $\begin{array}{l}\text { Very Serious } \\
\text { Problem }\end{array}$ \\
\hline Totality & 2.01 & 0.86 & Strongly Agree & $\begin{array}{l}\text { Very Serious } \\
\text { Problem }\end{array}$ \\
\hline
\end{tabular}

\section{Weighted Mean Interval Categorical Response Interpretation}

$\begin{array}{lll}\text { 3.26-4.00 } & \text { Strongly Disagree } & \text { Least Serious Problem } \\ 2.51-3.25 & \text { Disagree Slightly } & \text { Serious Problem }\end{array}$

1.76-2.50 Agree Serious Problem

1.00-1.75 Strongly Agree Very Serious Problem

\subsection{Problems Encountered by Parents as to Parenting}

As presented in table 5, the indicator that shows the highest weighted mean of 2.96 is indicator 13, stating "I do not have time to help my child in answering his/her modules," which has a categorical response Disagree, and interpreted as Slightly Serious Problem. This implies that parents don't have any problems in accommodating their child/children in doing their modules.

Parental involvement has been shown to have a substantial impact on students' achievement on the modular learning platform (Borup et al., 2014; Feng \& Cavanaugh, 2011; Lee \& Figueroa, 2012; Makrooni, 2019; Woofter, 2019). However, when their children participate in modular education, parents must assume new and unexpected roles and 
obligations, as well as increased instructional responsibility for their child's learning (Liu et al., 2010). As a result, parents frequently struggle to grasp their role in their children's modular education (Boulton, 2008; Murphy \& RodriguezManzanares, 2009). Parents have conflicting feelings about remote learning. Some parents are more involved with their children's academics than others, and some perceive this as a burden (Selwyn et al., 2011).

Furthermore, while parents must work from home and run the household, they must also keep their child/children on track with their modular schoolwork, which is why parents all over the world are naturally concerned about how their routines and the routines of their children are being disrupted. Parents have designed homemade timetables to address this problem, according to a study, ensuring that youngsters have something to do at all times and have a consistent sleep-wake cycle. Sticking to a schedule will make them and their children feel less restless and more productive. Rather than simply assuming that they could not satisfy their child's scholastic needs, parents have understood that this platform has provided them with seemingly infinite time, which may be a once-in-a-lifetime opportunity to try out new ways and ideas.

Moreover, the indicator with the lowest weighted mean of 1.74 is indicator number 11, stating, "I have more than one child, and I cannot facilitate more than a child at a time," which has a categorical response Strongly Agree and is interpreted as Very Serious Problem. This certainly means that most parents are worried about their child's future due to the new learning platform. An obstacle to children's educational progress was a lack of parent topic knowledge or pedagogy.

Parental problems have been identified as topic knowledge or pedagogy, as well as a lack of training to become an educator, which will certainly have an impact on the children's future. Furthermore, most students were concerned about their daily life and future opportunities as a result of the quick change from traditional to online schooling. Uncertainty about when life will return to "normal” causes anxiety (Daniel, 2020).

As a result, uncertainty about the future may detract from learners' desire for distance learning. Parents are concerned about their children's academic progress and successes at home when they lack motivation. While parents are concerned about their children's future, assisting low-motivated students in school can be challenging (Daniel, 2020). Similarly, the entirety of the weighted mean for problems encountered by parents in terms of parenting is 2.40 , with a categorical response of Disagree and interpreted as Slightly Serious Problem. At the same time, the overall standard deviation is 1.01 , indicating that all of the replies are dispersed, implying that the results are less credible.

Parents expressed their worries and challenges with the curriculum as a result of the findings. Several studies have been undertaken to support the assumption that when parents are involved in their children's education, they perform better (Bronfenbrenner, Karnes \& Lee, Florin \&Doke are cited by the State of Iowa Department of Education, 1998 p. 1). Academic development was one of the parents' main concerns, which overlapped with special learner requirements and curriculum issues. Parents didn't want their kids to fall behind in class. Parents want their children to receive a good education. Parents are expected to provide a safe and healthy environment, appropriate learning opportunities, support, and a positive attitude toward school because students' academic progress will be hindered if these factors are not present. Additionally, parental engagement in a student's education begins at home, with parents providing a safe and healthy environment, appropriate learning opportunities, support, and a positive attitude toward school. Several studies have revealed that children who involve their parents in their schooling perform better academically. (Epstein, 2009; Greenwood \& Hickman, 1991; Henderson \&Berla, 1994; Rumberger et al., 1990; Swap, 1993; Whitaker \& Fiore, 2001); Rumberger et al., 1990; Swap, 1993; Whitaker \& Fiore, 2001). Parental involvement is most effective, according to studies, when it is 
viewed as a collaborative effort between educators and parents (Davies, 1996; Emeagwali, 2009; Epstein, 2009). By analyzing parents' and teachers' perceptions, educators and parents should have a greater understanding of effective parental participation tactics in enhancing student accomplishment.

Table 5: Problems Encountered by Parents As To Parenting

\begin{tabular}{|l|c|c|l|l|l|}
\hline \multicolumn{2}{|c|}{ Indicator } & $\begin{array}{c}\text { Weighted } \\
\text { Mean }\end{array}$ & $\begin{array}{c}\text { Standard } \\
\text { Deviation }\end{array}$ & \multicolumn{1}{|c|}{$\begin{array}{c}\text { Categorical } \\
\text { Response }\end{array}$} & \multicolumn{1}{|c|}{ Interpretation } \\
\hline \multicolumn{5}{|c|}{ Carenting } \\
\hline $\begin{array}{l}\text { 11. I have more than one child, and } \\
\text { I cannot facilitate more than a child } \\
\text { at a time. }\end{array}$ & 2.07 & 1.07 & Strongly Agree & Very Serious Problem \\
\hline $\begin{array}{l}\text { 12. I am worried about my child's } \\
\text { future with this platform. }\end{array}$ & 1.74 & 0.79 & Agree & Serious Problem \\
\hline $\begin{array}{l}\text { 13. I do not have time to help my } \\
\text { child in answering his/her modules. }\end{array}$ & 2.96 & 1.10 & Disagree & Slightly Serious Problem \\
\hline $\begin{array}{l}\text { 14. I do not have time intended for } \\
\text { picking up my child/children's } \\
\text { module from school. }\end{array}$ & 2.93 & 1.22 & Disagree & Slightly Serious Problem \\
\hline $\begin{array}{l}\text { 15. I cannot manage to help my } \\
\text { kids learn while looking for ways } \\
\text { to earn. }\end{array}$ & 2.30 & 0.87 & Strongly Agree & Very Serious Problem \\
\hline \multicolumn{1}{|c|}{ Totality } & $\mathbf{2 . 4 0}$ & $\mathbf{1 . 0 1}$ & Disagree & Slightly Serious Problem \\
\hline
\end{tabular}

\section{Weighted Mean Interval Categorical Response Interpretation}

$\begin{array}{lll}\text { 3.26-4.00 } & \text { Strongly Disagree } & \text { Least Serious Problem } \\ 2.51-3.25 & \text { Disagree Slightly } & \text { Serious Problem }\end{array}$

1.76-2.50 Agree Serious Problem

1.00-1.75 Strongly Agree Very Serious Problem

\section{CONCLUSIONS}

In light of the findings from the research, it is consequently concluded that the parents of elementary learners in Sibonga Central Elementary School are experiencing numerous challenges during this new normal setup. These findings correspond and agree with Epstein's Overlapping Spheres of Influence Theory that demonstrates and suggests that both parents and teachers should make an effort mutually in terms of communicating, learning at home, and parenting to address parent's concerns in offering academic success to students because education is a vital determinant of a country's development. Parents must be prepared with competent tactics in order to care for and defend the world's future. Taking into account parents' perspectives on the impact of this new academic platform as a result of the epidemic would aid educators and policymakers in developing future plans.

\section{ACKNOWLEDGEMENT}

The researchers would like to happily thank the following significant people who have brought to the completion of this academic endeavor:

- Cebu Technological University and Argao Campus Administration led by Dr. Eingilbert C. Benolirao, for approving the conduct of the study. 
- The Department of Education - Province of Cebu administrators and supervisors for the opportunity to engage with parents.

- Parents of the Elementary Students of the Sibonga Central Elementary School for sparing their time in answering the survey questionnaires and for the constructive criticisms and bright ideas for the improvement of the study.

Above all, Jesus Christ, whose divine intervention made this endeavor a reality.

\section{REFERENCES}

1. Alghazo,Y. Ph.D. (2016, April).The Theory of Planned Behavior and Parental Involvement: A Theoretical Framework for Narrowing the Achievement Gaps. Retrieved from https://www.ijsr.net/archive/v5i4/NOV162664.pdf.

2. Alve, B.(2020,July31).New Normal: How Parents Embrace the Challenges in Education. Retrieved fromhttps://www.depedmalaybalay.net/articles/new-normal-how-parents-embrace-the-challenges-in-education.html.

3. Angrist, J.,LavyV. (1996, October).The Effect of Teen Child bearing and Single Parenthood on Childhood Disabilities and Progress in School. Retrieved from https://ideas.repec.org/p/nbr/nberwo/5807.html.

4. Bhamani, S., et al. (2020, June).Home Learning in Times of COVID: Experiences of Parents. Retrieved from https://files.eric.ed.gov/fulltext/EJ1259928.pdf.

5. Bunijevac, M., Durisic, M. (2017). Parental Involvement as an Important Factor for Successful Education. Retrieved from https://drive.google.com/file/d/1QuZmhmROq6PblBiCrQnhn9YeO1GGqJe8/view.

6. Cherry, K. (2020, September28). Parental Age and Child Development. Retrieved from https://www.verywellfamily.com/parental-age-impact-child-development-4150443.

7. CIA World Fact book(2020,November 27). Philippines Mother's Mean Age at First Birth. Retrieved from https://www.indexmundi.com/philippines/mother_s_mean_age_at_first_b $r$ h h.html

8. Clearinghouse Technical Assistance Team (2020,January6).Parent's. Educational Level Influence on Child Educational Outcomes: Rapid Literature Review. Retrieved from https://militaryfamilies.psu.edu/wp-content/uploads/2020/01/ParentsEducational-Levels-Influence-on-Child-EducationalOutcomes.20Jan06.final_pdf.

9. Cook,P.et.al(2020,December).Covid-19 and Remote Learning: Experiences of Parents with Children during the Pandemic..Retrieved from https://doi.org/10.29333/ajgr/8471.

10. Dado,N.(2020, August 9).Challenges Parents Facein Education's New Normal. Retrieved from https://www.google.com/amp/s/www.manilatimes.net/2020/08/09/busines.

11. Dangle, Y. Sumaoang,J. (2020, November27-29).The Implementation of Modular Distance Learning in the Philippine Secondary Public Schools. Retrieved from https://www.dpublication.com/wp content/uploads/2020/11/27-427.pdf.

12. Dep Ed Order No. 018, series of 2020. Policy Guidelines for the Provision of Learning Resources in the Implementation of the Basic Education Learning Continuity Plan. Retrieved from https://www.deped.gov.ph/wpcontent/uploads/2020/08/DO_s2020_018.pdf.

13. Duncan, G., et al. ( 2018, December ).Maternal Age and Child Development. Retrieved from https://www.ncbi.nlm.nih.gov/pmc/articles/PMC6392079/\#_ffn_sectitle.

14. Fabella,F., Leander, J.(2020,June 18). Parental Involvement and Academic Performances of Grade 7 Students. Retrieved from https://papers.ssrn.com/sol3/papers.cfm?abstract_id=3630178 
15. Family-School \& Partnerships Bureau, (2011).Parent Engagement in Children's Education. Retrieved from http://www.familyschool.org.au/files/7313/7955/4814/parent-engagement-in-childrens-education.pdf.

16. Gallagher, R.(2020). School's Out: A Parents' Guide for Meeting the Challenge During the COVID-19 Pandemic. $R$ e $t$ ri e ved from https://nyulangone.org/news/schools-out-parents-guide-meeting-challenge-during covid19pandemic

17. Garnet, A. et.al (2020, December).COVID-19 and Remote Learning: Experiences of Parents with Children during the Pandemic. Retrieved from https://drive.google.com/file/d/IQrFGdk8NgFRGHVLjBtwVEacQ3_mpsccz/view?usp=drivesdk.

18. Gooding,Y.(2001).The Relationship Between Parental Educational Level And Academic Success of College Freshmen. Retrieved from https://drive.google.com/file/d/IUV6Ibjx9cKEEIGplltT3__YAhN-yP.

19. Hall, R. (2021,February19).Women Doing Home Schooling During Lockdown than Men. Retrieved from https://www.google.com/amp/s/amp.theguardian.com/education/2021/feb/19/women-doing-more home-schooling-duringcovid-lockdown-than-men.

20. Lamar University(2019, April 09).How Parent's Educational Level Affect Children's Success. Retrieved

21. From https://degree.lamar.edu/articles/undergraduate/parents-education-level-and-childrens-success/.

22. Leander, J.(2020, July10).Parental Involvement and Academic Performance. Retrieved from https://papers.ssrn.com/sol3/papers.cfm?abstract_id=3630178

23. Journal of Education and Educational Development7(1), 09-26, 2020. Home Learning in Times of COVID: Experiences of Parents. Retrieved from https://files.eric.ed.gov/fulltext/EJ1259928.pdf

24. Manlangit, P.etal. (2020,October 5).Super charging Filipino Parents is Key for Successful Modular Distance Learning. Retrieved from https://www.flipscience.ph/news/features-news/tagapagdaloy modulardistancelearning/\#: :text=Modular\%20learning\%20is\%20a\%20form, '\%20an d\%20stude

25. $n t s^{\prime} \% 20$ desired\%20competencies.

26. Newchurch, A.(2017,October 30).The Impact of Parent al Involvement on Student Success: School and Family Partnership from the Perspective of Parents and Teachers. Retrieved from https://digitalcommons.kennesaw.edu/cgi/viewcontent.cgi? article=1022\&context=teachleaddoc_etd.

27. OECD Policy Responses to Coronavirus (COVID-19) (24 September 2020). Strengthening online learning when schools are closed: The role of families and teachers in supporting students during the COVID-19 crisis. Retrieved from https://www.oecd.org/coronavirus/policy-responses/strengthening-online-learning-when

schools-are-closed-the-role-offamilies-and-teachers-in-supporting-students-during-the-covid-19-crisis c4ecba6c/

28. Philippine Statistics Authority (2021, January 27). Registered Live Birth in the Philippines 2019. Retrieved from https://psa.gov.ph/vital-statistics/id/163858

29. Rahman,J. (2001,May).The Effect of Parents Involvement on Student Success. Retrieved from https://drive.google.com/file/d/1RIOjSeXFmcwvveeLtZ8LtbajpYbImGgp/view? usp=drivesdk

30. Salin (2020, November20).Challenges of Parental Involvement in Education. Retrieved from https://www.humanandhopeassociation.org/challenges-parental-involvement-education.

31. Sankar,A.(2020,April 29).Education in Times of COVID: How Students, Teachers \& Parents are Dealing with the Pandemic. Retrieved from https://thebastion.co.in/politics-and/education-in-times-of-covid-how-students-teachers-and-parents-aredealing-with-the-pandemic/ 
32. Stahl,A. (2020, May 01).New Study: Millennial Women are Delaying Having Children due to their Carriers. Retrieved from https://www.google.com/amp/s/www.forbes.com/sites/ashleystahl/2020/05/ 01/new-study millennial-women-are-delayinghaving-children-due-to-their-careers/amp

33. Valerie,L.(2020,November28).The Role of the Parents in Modular Distance Learning Retrieved from https://www.pressreader.com/philippines/sunstarpampanga/20201128/281681142436238

34. Walker, J.,Smrekar, C.Parenting: Influence Of Parents' Level Of Education. Retrieved from https://education.stateuniversity.com/pages/2311

35. Dr. Binoj Ravindran Nair, Dr. Ravindran Chirukandath Dr. Santhosh P.V \& Dr. Babu Pulluvelayil John, "Covid-19 Pandemic: Impact on Surgical Training and Trainee Perception: Need for Introspection and Strategy Change”, International Journal of Medicine and Pharmaceutical Sciences (IJMPS), Vol. 10, Issue 6, pp, 1-10

36. Sirisha Deepthi Sornapudi \& Meenu Srivastava, "Face Mask For Covid-19: A Social Responsibility”, International Journal of Agricultural Science and Research (IJASR), Vol. 10, Issue 3, pp, 1-6

37. Almetwally, Ehab M., and M. I. Gamal. "Discrete Alpha Power Inverse Lomax Distribution with Application of COVID-19 Data." International Journal of Applied Mathematics \& Statistical Sciences (IJAMSS) 9 (2020): 11-22.

38. Mufutau Akanmu Popoola, Shittu Muili Olawale \& Hamzart Kabirat Abosede, "Effect of COVID-19 Outbreak on Socioeconomic Development in Nigeria”, International Journal of General Medicine and Pharmacy (IJGMP), Vol. 9, Issue 5, pp; 29-36 
